\title{
Yükseköğretim Kurumu Öğrenci Disiplin Suçları, Cezaları ve Soruşturmalarına İlişkin Bazı Değerlendirmeler
}

\author{
Considerations on Disciplinary Crimes, Penalties and Proceedings in \\ regard to Students of Higher Education Institutions
}

\author{
Güneș Okuyucu Ergün* (iD, Eylem Baş* (iD)
}

\section{öz}

Disiplin cezaları ceza hukuku anlamındaki cezalara en benzeyen idari müeyyidelerdir. Bunlar ceza hukuku müeyyidesi olmamakla beraber, kimi zaman ceza hukuku anlamındaki cezalar kadar ağır sonuçlar doğurabilir. Yükseköğretim kurumu öğrencileri hakkında verilebilecek cezalar, bu durumun en iyi örneklerindendir. Örneğin yükseköğretim kurumundan çıkarma cezası, temel bir hak olan eğitim hakkının önemli ölçüde sınırlandırılması sonucunu doğurmaktadır. Dolayısıyla bu alanda da kanunilik ve hukuki güvenlik ilkelerinin gereklerine uygun düzenlemeler yapılmalıdır. 2547 sayılı Yükseköğretim Kanunu ve Yükseköğretim Kurumları Öğrenci Disiplin Yönetmeliği bu açıdan incelendiğinde, bazı hükümlerinin eleştiriye açık olduğu ve değiștirilmesinin uygun olacağı görülmektedir.

Anahtar Kelimeler: Disiplin Cezası, Disiplin Suçu, Disiplin Soruşturması, Yükseköğretim Kurumu, Yönetmelik

\section{ABSTRACT}

Disciplinary penalties constitute the type of administrative sanctions which are most similar to criminal law penalties. Although they are not criminal law penalties, their consequences may sometimes be as severe as that of criminal law penalties. The penalties to be given to the students of higher education institutions are among the best examples of that situation. For instance, the penalty of expulsion from the higher education institution results in a significant restriction of the right to education, which is a fundemental right. Therefore, the regulations on this matter should also comply with the requirements of the principles of legality and legal certainty. When the Higher Education Law No. 2547 and the Higher Education Institutions Disciplinary Regulation are analysed from that perspective, it is observed that some of their provisions are open to criticism and thus their amendment would be appropriate.

Keywords: Disciplinary Penalty, Disciplinary Crime, Disciplinary Proceeding, Higher Education Institution, Regulation

* Doç. Dr., Ankara Üniversitesi Hukuk Fakültesi Ceza ve Ceza Muhakemesi Hukuku Anabilim Dalı

** Ar. Gör. Dr., Ankara Üniversitesi Hukuk Fakültesi Ceza ve Ceza Muhakemesi Hukuku Anabilim Dalı, ebas@ankara.edu.tr

Sorumlu Yazar/Correspondence Author: Güneş Okuyucu Ergün

E-posta/E-mail: okuyucu@law.ankara.edu.tr

Geliş Tarihi/Received: $\quad 11.03 .2021$

Kabul Tarihi/Accepted:

31.03 .2021 


\section{GíRiş}

Ceza hukuku, insan haklarının hem kalkanı hem de kılıcıdır. ${ }^{1}$ Gerçekten de ceza kanunları, bir yandan temel hak ve özgürlükleri korumak amacına hizmet ederken bir yandan da bunlara yönelik birincil tehdit olabilmektedir. Ancak belirtmek gerekir ki sadece ceza hukuku müeyyideleri değil, aynı zamanda idari müeyyideler de temel hak ve özgürlüklerle yakından ilişkilidir. İdari müeyyidelerin bir türü olan disiplin cezaları ise, bu bağlamda özel bir önem arz etmektedir. Söz gelimi, "yükseköğretim kurumundan çıkarma” şeklindeki disiplin cezasının uygulanmasıyla yükseköğretim kurumu öğrencilik statüsü sona ermekte ve dolayısıyla temel bir insan hakkı olan eğitim hakkı önemli ölçüde sınırlandırılmış, hatta ortadan kaldırılmış olmaktadır. "Yükseköğretim kurumundan uzaklaştırma" cezası da benzer şekilde eğitim hakkının sınırlandırılması anlamına gelmektedir. Temel hak ve özgürlükler bakımından sınırlamalara yol açmaları nedeniyle disiplin cezalarına ilişkin kuralların açık ve belirgin bir şekilde ortaya konulması şarttır. Dolayısıyla ceza ve ceza muhakemesi hukukunda geçerli olan suçta ve cezada kanunilik ilkesi, savunma hakkına saygı ilkesi gibi ilkelerin disiplin hukukunda da geçerli olması gerekir. $^{2}$

Öte yandan her ne kadar ceza hukuku anlamındaki cezalara en benzeyen idari müeyyide disiplin cezaları olsa da bunların ceza hukuku müeyyidesi olmadığının altı çizilmelidir. ${ }^{3}$ Herşeyden önce, ceza müeyyidesi kanunlarda suç olarak tanımlanan filleri işleyen herkese uygulanabilen, genel düzeni korumaya yönelik müeyyideler iken; disiplin cezaları, sadece belirli bir statüye veya gruba dahil olan öğrenci, memur gibi belirli kimselere uygulanan ve idarenin kendi işleyişini ve iç düzenini korumaya yönelik müeyyidelerdir. ${ }^{4}$ Buna karşın disiplin cezalarının ceza hukuku anlamındaki cezalara nazaran daha hafif olduğu kanısı, doğurdukları önemli sonuçlar göz önüne alındığında her zaman doğru sayılmaz. ${ }^{5}$ Bir statüye dahil olmanın mahiyeti gereği, idarenin sahip olduğu bireyler üzerinde idari müeyyide (ve bu bağlamda disiplin cezası) uygulama yetkisi, idare ile olan ilişkilerden kaynaklanır ve belirli özel yükümlülüklerin yerine getirilmemesi halinde kullanılabilir. ${ }^{6}$

1 Bkz. TULKENS, Françoise: “The Paradoxical Relationship between Criminal Law and Human Rights”, Journal of International Criminal Justice (2011), Cilt 9, ss. 577-595, özl. s. 578 vd.

2 OĞURLU, Yücel: “Ceza Mahkemesi Kararının Disiplin Cezalarına Etkisi ve Sorunu "Ne Bis İn İdem” Kuralı”, Ankara Üniversitesi Hukuk Fakültesi Dergisi (2003), Cilt 52, Sayı 2, ss. 101-124, s. 101-102. Benzer yönde bkz TOROSLU, Haluk: Ceza Müeyyidesi, Ankara 2010, s. 18. Disiplin hukukunda da giderek kanunilik ilkesinin yerleşmeye başladığı; ancak hala mutlak biçimde uygulanmadığına dair bkz. CENTEL, Nur/ ZAFER, Hamide/ ÇAKMUT, Özlem: Türk Ceza Hukukuna Giriş, Beta Yayıncılık, Ankara 2020, s. 562.

3 ÖZAY, İl Han: İdari Yaptırımlar, İstanbul: İstanbul Üniversitesi Yayınları, İstanbul, 1985, 43. Disiplin cezaları ile ceza hukuku anlamındaki cezalar arasındaki farklar için yrıca bkz. CENTEL/ZAFER/ÇAKMUT, s. 562-563.

4 CENTEL/ZAFER/ÇAKMUT, s. 562; TOROSLU, H., s. 17; GÖZÜBÜYÜK, Şeref/TAN, Turgut: İdare Hukuku, Ankara $2006,977$.

5 Bkz. AİHM, Engel v. Netherlands, 08.06.1976, https://hudoc.echr.coe.int/tur\#\{\%22fulltext\%22:[\%22engels\%22],\%22 documentcollectionid 2\% 22: [\%22GRANDCHAMBER\%22,\%22CHAMBER\%22], \%22 itemid\%22: [\%22001-7479\%22]\}, 2020; AİHM, Albert and Le Comptev. Belgium, 10.02.1983, https://

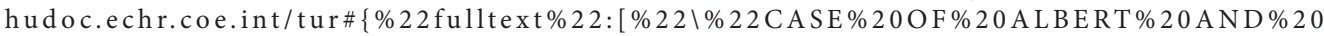
LE \% 20 C OM P T E \% 20 v. \% 20 B E L G I U M \\% $22 \% 22$ ], \% 22 s ort \% 22 : [ \% 22 a p p n o y a r \% 20 Ascending, appnocode \%20 Ascending\%22],\%22 documentcollectionid 2\%22:[\%22GRANDCHAMBER \%22,\%22CHAMBER\%22],\%22itemid\%22:[\%22001-57422\%22]\}, 2020; OĞURLU, s. 101-102.

6 ZANOBINI, Guido: İdari Müeyyideler (Çev. H. Yılmaz Günal), Ankara Üniversitesi Siyasal Bilgiler Fakültesi Yayınları, Ankara, 1964, s. 18. Aynı yönde olmak üzere, disiplin müeyyidelerinin belirli bir gruba dahil olan kimselerin, davranışlarını düzenleyen kurallara uymalarını sağlamaya yönelik müeyyideler oldukları hakkında bkz. AİHM, Weber 
İşte yükseköğretim kurumu öğrencileri de bu kapsamda yer almaktadır. Nitekim yükseköğretim kurumunun iç çalışma düzenini, başka bir deyişle idari düzenini korumak ve yürütülen hizmetin düzgün işlemesini sağlamak amacıyla, yükseköğretim kurumu yönetimlerince bu kurumdan hizmet alanlar, yani öğrenciler hakkında disiplin cezaları uygulanmaktadır." Anayasanın "Yükseköğretim Kurumları" başlığını taşıyan 130/9. maddesinde "disiplin ve ceza işleri”nin kanunla düzenleneceği öngörülmüştür. Bu kapsamda 2547 sayılı Yükseköğretim Kanunu (2547 sayılı Kanun) m. 54’te yükseköğretim kurumu öğrencilerinin disiplin yönünden soruşturulmalarına ilişkin hususlarla, haklarında verilecek disiplin cezaları düzenlenmiştir. Ancak söz konusu hükmün genel çerçeveyi çizmekle yetindiği görülmektedir. Bu kapsamda 2547 sayılı Kanun m. 54 ile "Yönetmelikler" başlıklı m. 65-ảnın (9) numaralı düzenlemesine dayanılarak 'Yükseköğretim Kurumları Öğrenci Disiplin Yönetmeliğì' (Yönetmelik) çıkarılmıştır. ${ }^{8}$ Nitekim 2547 sayılı Kanun m. 65’te "öğrencilerin disiplin işlemleri, disiplin amirlerinin yetkileri ve disiplin kurullarının teşkili ve çalışması ile ilgili hususlar"ın "Yükseköğretim Kurulu tarafından çlkarılacak yönetmeliklerle düzenle"neceği öngörülmüştür.

Yönetmelik toplamda beş bölümden oluşmaktadır. Birinci Bölüm’de amaç, kapsam, dayanak ve tanımlar; İkinci Bölüm'de disiplin cezaları ve disiplin cezalarını gerektiren disiplin suçları; Üçüncü Bölüm'de disiplin soruşturmas1; Dördüncü Bölüm’de uygulama ve itiraz düzenlenmektedir. "Çeşitli ve Son Hükümler" başlıklı Beşinci Bölüm’de ise, tebligat ve adres bildirmeye, dosya teslimine, yazışma şekline ve Yönetmeliğin yürürlüğüne ilişkin maddeler yer almaktadır.

Yönetmelik m. 1 uyarınca Yönetmelik "yükseköğretim kurumları öğrencilerine verilecek disiplin cezaları ile soruşturma usul ve esaslarını" düzenlemek amacıyla çıkarılmış olup, "yükseköğretim kurumlarındaki tüm öğrencileri” kapsamaktadır. Yönetmelik m. 3-a’ya göre öğrenci “yükseköğretim kurumlarında önlisans, lisans, yüksek lisans, doktora, tıpta uzmanlık veya sanatta yeterlilik öğrenimi gören kişiler”i ifade etmektedir. Ancak uygulamada yükseköğretim kurumu öğrencilerinin disiplin yönünden soruşturulmaları ve haklarında verilecek disiplin cezaları bakımından hukuki sorunların varlığı göze çarpmaktadır. Bu çalışmada, 2547 sayılı Kanun m. 54 ile Yönetmelik hükümleri dikkate alınmak suretiyle söz konusu sorunlarla ilgili bazı değerlendirmelerde bulunulacaktır.

\section{2547 SAYILI KANUN'DA DÜZENLENEN ÖĞRENCI DISIPLIN SUÇLARI VE CEZALARI}

Yükseköğretim Kurumu öğrencilerinin disiplin cezasını gerektiren filleri 2547 sayılı Kanun m. 54-a’da sayılmıştır. Buna göre öğrenci disiplin suçları "yükseköğretim öğrenciliği sıfatına, onur ve şerefine aykırı harekette" bulunmak; "öğrenme ve öğretme hürriyetini, doğrudan doğruya veya dolaylı olarak" kısıtlamak; "kurumların sükûn, huzur ve çalışma düzenini bozan, boykot, işgal ve

v. Switzerland, 29.06.2006, https://hudoc.echr.coe.int/fre\#\{\%22itemid\%22:[\%22001-76586\%22]\}, 2020.

7 ULUSOY, Ali: İdari Yaptırımlar, On İki Levha Yayıncılık, İstanbul, 2013, s. 169.

828388 sayılı ve 18.08.2012 tarihli Resmî Gazete. Yönetmelik m. 30 ile 18634 sayılı ve 13.01.1985 tarihli Resmî Gazete’de yayımlanarak kendisi yürürlüğe girinceye kadar yürürlükte olan 'Yükseköğretim Kurumları Öğrenci Disiplin Yönetmeliği’ni yürürlükten kaldırılmıştır (Danıştay İdari Dava Daireleri Genel Kurulu (DİDDGK) 2014/843 E. 3.11.2014 T. www.kazanci.com, 2020). 
engelleme gibi eylemlere” katılmak; “bunları teşvik ve tahrik” etmek; “yükseköğretim mensuplarının şeref ve haysiyetine veya şahıslarına tecavüz eden veya saygı dışı davranışlarda” bulunmak ve "anarşik veya ideolojik olaylara” katılmak "veya bu olayları tahrik ve teşvik” etmekten ibarettir.

Söz konusu fiiller "başka bir suçu oluştursa bile" bu fiilleri gerçekleştiren öğrenciler hakkında ayrıca "uyarma", "kınama", "bir haftadan bir aya kadar veya bir veya iki yarıyıl için kurumdan uzaklaştırma" ya da "yükseköğretim kurumundan çıkarma cezaları”nın verileceği öngörülmüştür. Gerçekten de hukuka aykırı bir fiilin birden fazla yaptırımla karşılanması mümkündür ve bunun en tipik örneğini disiplin cezaları oluşturmaktadır. Söz konusu durum bu iki tür cezanın birbirinden ayrı olduğunu da göstermektedir. ${ }^{9} 2547$ sayılı Kanun'da başka bir suçu oluşturması halinde ayrıca disiplin cezasının da verileceğinin öngörülmesi, kanunkoyucunun bu durumu 'ne bis in idem ilkesi'ne aykırı görmediği şeklinde yorumlanmıştır. ${ }^{10}$

2547 sayılı Kanun m. 54’teki disiplin cezalarına ilişkin sayma, sınırlı sayma niteliğindedir ve öğrenci disiplin suçları karşılığında bu ceza türleri dışında bir cezanın uygulanması mümkün değildir. Dolayısıyla burada sayılan cezalar dışında bir cezanın soruşturmacılar tarafından verilmesi mümkün olmadığı gibi, yönetmelikle öngörülmesi de söz konusu olamaz.

Disiplin hukukunda disiplin cezaları bakımından kanunilik ilkesi benimsenmiş olmasına karşın aynı şeyin disiplin suçları için söylenmesi mümkün değildir. Nitekim Yönetmeliğin "Öngörülmemiş Disiplin Suçları” başlığını taşıyan 10. maddesinde "uyarma ve kınama cezası verilmesini gerektiren” disiplin suçlarına "nitelik ve ağırlıkları itibarıyla benzer" fiilleri gerçekleştirenler hakkında hangisine benziyorsa ona göre "uyarma” ya da "kınama" cezasının verileceği öngörülmekle kıyasa izin verilmiş olmaktadır. $^{11}$

Mülga Yönetmeliğin aynı başlıklı 11. maddesi ise, yalnızca uyarma ve kınama cezası gerektiren disiplin suçları bakımından değil, yükseköğretim kurumu öğrencileri hakkında uygulanması mümkün olan tüm disiplin suçları bakımından kıyası mümkün kılmıştı. Bu açıdan yürürlükteki Yönetmelik bir ilerlemeyi ifade etse de bunun yeterli olmadığı da belirtilmelidir.

Disiplin suçu oluşturan fiillerin açık ceza normu şeklinde düzenlendiği hatta genellikle yönetmelikle belirlenmelerinin olağan bir uygulama haline geldiği görülmektedir. Bu durum çoğunlukla pratik gereklerle izah edilmeye çalışılmakta, öğrenciler hakkında disiplin cezası verilmesini gerektiren her bir fiilin kanunla düzenlemesinin fiilen mümkün olmadığı belirtilmektedir. ${ }^{12}$ Bu uygulamanın yerinde olmaması bir yana, 2547 sayılı Kanun m. 54-a’nın bir açık ceza normu niteliği dahi taşımadığı belirtilmelidir. Zira söz konusu hükümde disiplin suçu teşkil eden bazı fiiller belirtilmekle beraber, hangi fiile hangi cezanın uygulanacağı belirlenmemekte; disiplin suçu teşkil eden fiiller ile bunların karşılığı olacak cezalar peş peşe sıralanmakta, ancak birebir eşleştirilmemektedir. Dolayısıyla anılan madde bir çerçeve hüküm bile sayılmaz. Ayrıca maddede ne tür fiillerin disiplin suçu sayılabileceğine

9 DERBİL, Süheyp: İdare Hukuku, Ankara Üniversitesi Hukuk Fakültesi Yayınları, Ankara, 1955, 398.

10 OĞURLU, s. $101 \mathrm{vd}$.

11 CENTEL/ZAFER/ÇAKMUT, s. 563.

12 ULUSOY, s. 170. 
dair bir çerçeve tanımdan ziyade suçların adları belirtilip geçilmiştir. Bunun ise kanunilik ilkesine aykırı olduğu açıktır. Bu haliyle öğrencilerin hangi fiillerinin disiplin suçu oluşturacağı son derece belirsiz ve tamamen yoruma açıktır. Dolayısıyla olaydan olaya ve kişiden kişiye değişen uygulamalara yol açacak niteliktedir. Bu durumda söz konusu hüküm her bir soruşturmacı tarafından farklı biçimde yorumlanabilecek ve dolayısıyla benzer olaylara ilişkin farklı ve çelişkili kararlar ortaya çıkabilecektir. Buna bir de hukuk fakülteleri dışındaki yükseköğretim kurumlarında soruşturmaların hukukçu olmayan kimseler tarafından yapılması eklenildiğinde, durum daha da vahim bir hal alabilecek niteliktedir.

Anayasa Mahkemesi (AYM), 2547 sayılı Kanun’un söz konusu hükmüyle benzer nitelik taşıyan "Sağlık Hizmetleri Temel Kanunu” m. 3’ün “...katılmakla yükümlü olduğu hizmet içi eğitim programlarına uymayan veya bu programlarda başarılı olamayan sağlık personeline; kamu kuruluşunda çalışanlar için ilgili Bakanlığın, serbest çalışanlar için kayıtlı olduğu kamu kurumu niteliğindeki meslek kuruluşlarının görüşü alınmak suretiyle Sağlık ve Sosyal Yardım Bakanlığınca geçici veya daimî meslekten uzaklaştırma cezası verilir." şeklindeki (h) bendi bakımından "hizmet içi eğitim programına uymamak" fiilinin içeriğinin belirsiz olduğuna ve cezalardan hangisinin hangi durumda verileceğine ilişkin bir belirlemeye gidilmesi konusunda yönetime oldukça geniş bir takdir yetkisi verildiği anlamına geldiğine, bunun Anayasa’nın “ceza ve ceza yerine geçen güvenlik tedbirleri”nin “ancak kanunla konu”labileceğine ilişkin 38. maddesinin 3. fikrasına aykırılık oluşturduğuna ve bu nedenle de iptaline karar vermiştir. ${ }^{13}$

AYM, 2547 sayılı Kanun'un inceleme konusu hükmüne paralel nitelikteki m. 53-b’nin son iki cümlesiyle ilgili olarak da Anayasa’ya aykırı olduğuna ve bu nedenle de iptaline karar vermiştir. ${ }^{14}$ 2547 sayılı Kanun m. 53-b’nin iptal edilen son iki cümlesi şu şekildedir: "Öğretim elemanları, memur ve diğer personele uygulanabilecek disiplin cezaları uyarma, kınama, yönetim görevinden ayırma, aylıktan kesme, kademe ilerlemesinin durdurulması, üniversite öğretim mesleğinden çıkarma ve kamu görevinden çıkarma cezalarıdır. Hangi fiillere hangi disiplin cezasının uygulanacağı, bu bentte sayılan kişilerin disiplin işlemleri ve disiplin amirlerinin yetkileri, Devlet memurlarına uygulanan usul ve esaslar da göz önüne alınmak suretiyle Yükseköğretim Kurulunca düzenlenir."

Söz konusu hükme ilişkin iptal gerekçesinde, Anayasa m. 38'deki suç ve cezaların kanuniliği ilkesine ve suç ve cezalara ilişkin düzenlemelerin şekli bakımdan kanun biçiminde çıkarılmasının yeterli olmayip kanunun metninin, bireylerin hangi somut fiil ve olguya hangi hukuksal yaptırımın veya sonucun bağlandığını belirli bir açıklık ve kesinlikte öngörebilmelerine imkân verecek düzeyde kaleme alınmalarının da gerektiğgine vurgu yapılmıştır. Anayasa m. 128/2 uyarınca "Memurların ve diğer kamu görevlilerinin nitelikleri, atanmaları, görev ve yetkileri, hakları ve yükümlülükleri, aylık ve ödenekleri ve diğer özlük işleri kanunla düzenlenir.” Anyasa m. 130/9'da ise, disiplin ve ceza işlerinin kanunla düzenleneceği öngörülmüştür. Dava konusu kural ile düzenlenmesi öngörülen hususlar, hangi fiillerin hangi disiplin cezalarını gerektireceği, bentte sayılan kişilerin disiplin işlemleri ve disiplin amirlerinin yetkileri gibi konuları içermektedir. Söz konusu disiplin işlemleri,

13 AYM, 1987/16 E. 1988/8 K. 19.4.1988 T. 19908 sayılı 23.08.1988 tarihli Resmî Gazete.

1429319 sayılı 7.4.2015 tarihli Resmî Gazete. 
Anayasa’nın yukarıda yer alan hükümleri gereğince kanunla düzenlenmesi öngörülen hususlardır. $\mathrm{Bu}$ hâliyle öğretim elemanları, memurlar ve diğer personel için getirilmiş herhangi bir kanuni güvence bulunmadığı gibi yasal olarak belirlilik de sağlanmamıştır. Disiplin uygulamaları ile ilgili olarak genel ilkeleri ortaya koymayan, disiplin cezalarını gerektiren hâl ve durumları belirlemeyen, kapsama dâhil personelin disiplin işlemlerine dair usul ve esasları kanunda göstermeyerek, tüm bu işlemlerin Yükseköğretim Kurulunca düzenlenmesini öngören dava konusu kural, AYM tarafından Anayasa m. 38., 128. ve 130'a aykırı olduğu gerekçesiyle iptal edilmiştir. ${ }^{15}$

AYM'nin olası bir Anayasa'ya aykırlık iddiası halinde, benzer bir yorumla, 2547 sayılı Kanun m. 54 'ün de iptaline karar vermesi kuvvetle muhtemeldir. Ayrıca AYM'nin bu son kararında Anayasa m. 130'a aykırılıktan bahsetmesi ve disiplin suç ve cezaları bakımından kanunilik ilkesini vurgulaması ayrı bir öneme sahiptir. Gerçekten de 2547 sayılı Kanun m. 54-a, Anayasa m. 38 ve 130'a aykırıdır ve bu nedenle iptali gerekir. Zira Anayasa’nın disiplin ve ceza işlerinin kanunla düzenleneceğini öngören 130-9 maddesinin kapsamına yalnızca “öğretim elemanları, memur ve diğer personel” değil, aynı zamanda 'yükseköğretim kurumu öğrencileri' de dahildir. Ayrıca AYM’nin kararında isabetle belirttiği üzere, disiplin suç ve cezaları bakımından da kanunilik ilkesi geçerli olmalıdır.

Bununla beraber maalesef DİDDGK’nin içtihadı, 2547 sayılı Kanun'un "hem hangi eylemlerin disiplin suçunu oluşturacağını hem de hangi cezaların verilebileceğini saymak suretiyle genel bir çerçeve çizdiği”'16; Yönetmelik maddelerinde öngörülen disiplin suç ve cezalarının, 2547 Sayılı Kanun m. 54’te belirlenen genel çerçeve içerisinde kaldığı, ölçülülük ilkesi ve üst hukuk normlarına aykırı olmadığı yönündedir. ${ }^{17}$

2547 sayılı Kanun m. 54-a uyarınca sadece yükseköğretim kurumları içinde gerçekleştirilen fiiller değil, yükseköğretim kurumu dişında gerçekleştirilen fiiller de disiplin suçu oluşturabilecektir. Buna göre (a) bendi kapsamında sayılabilecek fiillerden biri, yüksek öğretim kurumu dişında gerçekleştirilmiş olsa dahi, söz konusu fiili gerçekleştiren öğrenciye disiplin cezası uygulanabilecektir. Ancak bu durum, disiplin hukukunun mahiyetiyle bağdaşmamaktadır. Zira disiplin hukuku bir kurumun iç düzenini bozmaya yönelik davranışlar bakımından uygulama alanı bulmaktadır ${ }^{18}$ ve öğrencinin yükseköğretim kurumu dışında gerçekleştirdiği her fiilin yükseköğretim kurumunun disiplinini bozduğu söylenemez. Dolayısıyla bir lisans öğrencisinin yükseköğretim kurumu dişında gerçekleştirdiği bir davranış nedeniyle hakkında disiplin soruşturması yürütülerek ceza verilmesi yerinde değildir. Buna göre, örneğin bir lisans öğrencisi yükseköğretim kurumu dışında, öğrenci olmayan bir kimseye karşı, cinsel saldırı suçunun basit şeklini gerçekleştirdiğinde, hakkında Yönetmeliğin “yükseköğretim kurumundan çıkarma cezasını gerektiren disiplin suçları” başlığını taşıyan 9. maddesinin, "kişilerin vücudu üzerinde cinsel davranışlarda bulunmak suretiyle cinsel dokunulmazlıklarını ihlal etmek" şeklindeki (ç) bendi hükmü uygulanacaktır. Anılan hükümde bu disiplin suçunu oluşturan davranışın yükseköğretim kurumu içinde ya da dışında gerçekleştirilmesi

1529319 sayılı 7.4.2015 tarihli Resmî Gazete.

16 DIDDGK 2014/843 E. 3.11.2014 T. www.kazanci.com, 2020.

17 DİDDGK 2016/4019 E. 2017/1660 K. 19.4.2017 T. www.kazanci.com, 2020.

18 YILMAZ, Ejder: Hukuk Sözlüğ̈̈, Yetkin Yayınları, Ankara, 2005. 
arasında ayrım gözetilmemiştir. Halbuki bu öğrenci hakkında gerçekleştirdiği fiil nedeniyle zaten 5237 sayılı Türk Ceza Kanunu’nun (TCK) “cinsel saldırı" başlıklı 102. maddesinin 1. fikrası nedeniyle ceza soruşturması ve kovuşturması gerçekleştirilecektir. Yönetmelik m. 7/1 - (ç), 8/1 (ç) ve (e)'de öngörülen eylemlerin yükseköğretim kurumu dışında işlenmesi durumunun disiplin suçunu oluşturmamasının hukuka aykırı olduğu ileri sürülen davada DIDDGK 2547 sayılı Kanun m. 54-a'daki düzenlemede, disiplin suçunu oluşturan eylemlerin yükseköğretim kurumları içinde veya dışında işlenmesi arasında bir fark bulunmamakla birlikte, uygulamada karşılaşılan sorunlardan yola çıkılarak anılan fiillerin sadece yükseköğretim kurumu içerisinde işlenmesi durumunun cezalandırılmasını öngören ve öğrencilerin lehine olan bu düzenlenmeleri hukuka aykırı görmemiştir. ${ }^{19}$

Söz konusu kararın mefhumu muhalifinden örneğin Yönetmelik m. 9-ç’nin DİDGK’nin önüne götürülmesi halinde Kurul'un bu hükmü hukuka aykırı görmeyeceği öngörülebilir. Ancak az evvel verilen cinsel saldırı suçu örneği bakımından öğrencinin yükseköğretim kurumunun iç düzenini bozduğundan bahsedilemez. Özellikle de Anayasa'da öngörülen ve temel bir hak olan "eğitim ve öğretim” hakkına ölçüsüz bir müdahale söz konusu olmaması için 2547 sayılı Kanun m. 54’te yapılacak bir değişiklikle disiplin suçlarının Yükseköğretim Kurumu içinde gerçekleştirilecek davranışlar ve dişarda yapılmakla birlikte yükseköğretim kurumunun düzenini bozan davranışlar ile sınırlandırılması daha doğru olacaktır. Böylece örneğin bir lisans öğrencisinin yükseköğretim kurumu dışında hocasını tehdit etmesi gibi, dışarda gerçekleştirilse dahi kurumunun iç düzenini ve disiplinini bozucu fiiller de kapsam dışında kalmamış olacaktır. Nitekim Danıştay "davacının okulda meydana gelen kopya olayını okul dışına taşıyarak arkadaşının evine gittiği ve fiili tecavüzde bulunmasının disiplin cezasıyla cezalandırılması hukuka aykırı görülmemiştir. ${ }^{20}$

\section{YÖNETMELIKTE DÜZENLENEN ÖĞRENCi DisiPLIN SUÇ VE CEZALARI}

\section{A. GENEL OLARAK}

Öğrenciler hakkında uygulanması mümkün olan disiplin cezaları, Yönetmeliğin "Disiplin Cezaları ve Disiplin Cezalarını Gerektiren Disiplin Suçları" başlıklı "İkinci Bölüm”ünde düzenlenmektedir. Buna göre, öğrenci disiplin cezaları, 2547 sayılı Kanun m. 54 esas alınmak suretiyle, 4 ila 9. maddelerde düzenlenmektedir. Yönetmelik m. 3’te ise, bu cezalar tanımlanmaktadır. Ancak söz konusu tanımlama gelişigüzel ve özensiz biçimde yapılmıştır. ${ }^{21}$ Nitekim bu cezaların mantık kuralları gereği en hafifinden en ağırına doğru sıralanması gerekirken bu sıralamaya uyulmamıştır. Yönetmelik m. 3’teki sıralama, "kınama", "uyarma”, "yükseköğretim kurumundan bir haftadan bir aya kadar uzaklaştırma", "yükseköğretim kurumundan bir yarıyl için uzaklaştırma”, "yükseköğretim kurumundan çıkarma”, "yükseköğretim kurumundan iki yarıyıl için uzaklaştırma” şeklindedir.

19 2016/4019 E. 2017/1660 K. 19.4.2017 T. www.kazanci.com 2020.

20 Danıştay 8. Dairesi 1998/4045 E. 1998/4564 K. 24.12.1998 www.kazanci.com 2020.

21 ARPACIOĞLU, Işıl Tüzün/ MORGÜL: Şükran, "Yükseköğretim Kurumları Öğrenci Disiplin Hukukuna 18.08.2012 Tarih ve 28388 Sayılı Resmi Gazetede Yayımlanarak Yürürlüğe Giren Yükseköğretim Kurumları Öğrenci Disiplin Yönetmeliği ile Getirilen Yenilikler Üzerine Bir Değerlendirme”, Electronic Journal of Vocational Colleges (2013), Aralık UMYOS Özel Say1, 79-86, s. 79. 
Yönetmelik m. 23 “disiplin cezası verilirken dikkat edilecek hususlar” düzenlemektedir. Buna göre, "disiplin cezalarını vermeye yetkili amirler ile disiplin kurulları bu cezalardan birini verirken, disiplin suçunu oluşturan eylemlerin ağırlığını, soruşturulan öğrencinin daha önce bir disiplin cezası alıp almadığını, davranış, tavır ve hareketlerini, işlediği fiil ve yaptığg hareket dolayısıyla pişmanlık duyup duymadığını dikkate alırlar”. Ancak bu hükümden ne anlaşılması gerektiği belirsizdir ve mutlaka açıklığa kavuşturulması gerekmektedir. Her ne kadar uygulamada, bu maddenin bir alt disiplin cezasının uygulanması şeklinde hayata geçtiği görülmekteyse de hükümden bunun bir alt cezaya çevrilmesi ve hatta illa ki cezanın indirilmesinin gerektiği anlaşılmamaktadır. Bu kapsamda örneğin "yükseköğretim kurumundan bir haftadan bir aya kadar uzaklaştırma cezasını gerektiren disiplin suçları”ndan birinin öğrenci tarafından işlenmesi halinde, işlenen bu suçun ağırlığı dikkate alınarak öğrenci hakkında bir aylık bir uzaklaştırma cezasının uygulanmasına karar verilmesi; ancak öğrencinin duyduğu pişmanlık nedeniyle bu cezanın bir haftaya düşürülmesinin mümkün olması gerekmesine karşın, uygulamada bir alt ceza verilmesi gerektiği kabul edilmektedir. Mülga Yönetmeliğin bu maddeye karşılık gelen 30. maddesinde de bunun bir alt ceza olması gerektiği belirtilmemesine rağmen uygulamada bir alt ceza verilmekteydi. DİDDGK davacının disiplin dışı fiil ve hareketlerinin sabit olduğu olayda “eyleminin amacı, niteliği ve ağırlığı dikkate alındığında davacı hakkında Yükseköğretim Kurumları Öğrenci Disiplin Yönetmeliği’nin bir alt ceza verilmesi konusunu düzenleyen 30. maddesinin uygulanamayacağı"na hükmetmişti. ${ }^{22}$ Yine bir başka kararında Danıştay, fakülte yönetim kurulunca da disiplin cezası verilirken öğrencinin daha önce hiç ceza almamış olması hali de dikkate alındığ sınırının verildiği olayda disiplin hukukunda bir alt ceza uygulamasının anlamının, eylemin karşılığı olan cezanın alt sınırı değil bir alt ceza türü olduğunu kabul etmiştir. ${ }^{23}$

Yönetmelik m. 23’te açıkça bir alt ceza verilmesinden bahsedilmemesi karşısında örneğin "yükseköğretim kurumundan çıkarma” cezasını gerektiren bir fiil nedeniyle disiplin amirinin lafzi yorum yapmak suretiyle sırf bu maddeyi uygulayarak öğrenci hakkında hiç ceza vermemesi ya da yalnızca "uyarma” cezası vermesi mümkün hale gelmektedir. Öğrenciye hiçbir ceza verilmemesi halinde işin doğası gereği öğrencinin bu işleme itiraz etmesi ya da doğrudan işleme karşı iptal davası açması beklenemez. Hatta iptal davası açılsa dahi, idare mahkemesi öğrencinin lehine görerek bu hükmü iptal etmeyebilir. Bu durumda bu hükmün uygulanması bakımından öğrenciler arasında farklı ve keyfi uygulamalar söz konusu olabilecek; dolayısıyla Anayasa’nın 10. maddesinde öngörülen "kanun önünde eşitlik" ilkesi ihlal edilmiş olacaktır. Zira disiplin cezalarının haklarında uygulandıkları kişiler bakımından eşit şekilde uygulanması gereklidir. ${ }^{24} \mathrm{Bu}$ nedenle uygulamada benimsenen bir alt cezanın verilmesinin açıkça hükümde öngörülmesi gereklidir.

22 DİDDGK 2004/2534 E. 2007/2426 K. 29.11.2007 T. www.kazanci.com 2020.

23 Danıştay 8. Dairesi 1996/1016 E. 1998/810 K. 5.3.1998 T. emsal.danistay.uyap.gov.tr, 2021.

24 GÜNAL, Yılmaz: “Disiplin Cezaları”, Ankara Üniversitesi Siyasal Bilgiler Fakültesi Dergisi (1958), Cilt 13, Sayı 2, ss. 190211, s. 196. 


\section{B. UYARMA CEZASI GEREKTIREN DISIPLIN SUÇLARI}

“Uyarma” cezası Yönetmelik m. 3-c’de “öğrencinin, öğrencilikle ilgili davranışlarında daha dikkatli olması gerektiği hususunda yazılı olarak ikaz edilmesi” şeklinde tanımlanmıştır. Eğer yazılı uyarı yapılmış ancak yazının içeriğinde açıkça “uyarma cezası” olduğu belirtilmemişse, bu yazının öğrencinin özlük dosyasına konması ve menfaatini zedelemesi ihtimaline binaen, bunun icrai bir idari işlem olarak görülmesi ve "uyarma cezası"nın sebep unsuru açısından denetimin yapılmasının mümkün olduğu kabul edilmelidir. ${ }^{25}$ Nitekim 2547 sayılı Kanun m. 54-d’de disiplin cezalarının, ilgili öğrenciye yazı ile bildirilmesi öngörülmüştür.

Yönetmelik m. 4’te "uyarma” cezasını gerektiren disiplin suçları 3 bent halinde sayılmıştır:

“a) Yükseköğretim kurumu yetkililerince sorulan hususları haklı bir sebep olmadan zamanında cevaplandirmamak,

b) Yükseköğretim kurumu yetkililerince tesbit edilen yerler dışında ilan asmak,

c) Yükseköğretim kurumunun izniyle asılmış duyuruları, program ve benzerlerini koparmak, yırtmak, değiştirmek, karalamak veya kirletmek"

Söz konusu madde incelendiğinde pek çok problem göze çarpmaktadır. Öncelikle Yönetmelik m. 4-a’da öngörülen “yükseköğretim kurumu yetkilileri”nin kim ya da kimler olduğu belli değildir. Buna göre yükseköğretim kurumunda yetkili kılınan tüm personelin bu kapsamda değerlendirilip değerlendirilemeyeceği belirsizdir. Mevcut haliyle düzenlemenin kapsamı aşırı geniş ve belirsizdir. Bununla beraber, Yönetmelik m. 9-a’da “yükseköğretim kurumu görevlilerine karşı cebir ve şiddet kullanarak görevin yapılmasına engel olma”nın ayrı bir disiplin suçu olarak öngörülmesi karşısında 'yetkili' ve 'görevli' kavramlarının aynı şeyi ifade etmediği söylenmelidir. Ayrıca burada yetkililerce "sorulan hususlar"dan bahsedilmekte; ancak bu hususların neyle ilgili olduğuna ilişkin bir belirleme yapılmamaktadır. Bu ise, hükmün geniş ve keyfi biçimde uygulanmasına yol açacak niteliktedir. Bununla beraber burada amaçsal yorum yapılarak bunların her türlü husus değil, cevaplandırılmaması kurumun iç düzenini bozacak hususlar olduğu kabul edilmelidir. "Zamanında cevaplandırmamak" ibaresi de açık değildir. Bu koşulun ne zaman gerçekleşmiş sayılacağına dair ölçütlere yer verilmelidir.

Yönetmelik m. 4-b de belirsiz ve farklı uygulamalara yol açabilecek niteliktedir. Yükseköğretim kurumu yetkililerinin belirledikleri yerler dışında asılacak her türlü ilan bu kapsamda değerlendirilmeye müsaittir. Ancak burada da amaçsal yorum yapılmalı ve kurumun iç düzenini ve disiplinini bozmaya elverişli olmayan ilanlar bu kapsamda değerlendirilmemelidir. Örneğin bir öğrencinin ev arkadaşı aradığına ilişkin yükseköğretim kurumunun girişinde bir ağaca ya da duvara ilan asması bu kapsamda düşünülmemelidir. 


\section{KINAMA CEZASI GEREKTIREN DISIPLIN SUÇLARI}

Yönetmelik m. 3-b’ye göre "Kınama” cezası “öğrenciye öğrencilikle ilgili kusurlu davranışlarından dolayı kınandığının yazılı olarak bildirilmesi”dir. Kınama cezasını gerektiren disiplin suçları ise Yönetmelik m. 5’te beş bent halinde sayılmıştır:

“a) Yükseköğretim kurumu yetkililerince istenilen bilgileri eksik veya yanlış bildirmek,

b) Ders, seminer, uygulama, laboratuvar, atölye çalışması, bilimsel toplantı ve konferans gibi çalışmaların düzenini bozmak,

c) Yükseköğretim kurumu içinde izinsiz olarak bildiri dağıtmak, afiş ve pankart asmak,

ç) Yükseköğretim kurumunca asılmış duyuruları, program ve benzerlerini koparmak, yırtmak, değiştirmek, karalamak veya kirletmek,

d) Sinavlarda kopyaya teşebbüs etmek.”

Bu hükme bakıldığında da bazı sorunların varlığı göze çarpmaktadır. Nitekim Yönetmelik m. 4-a kapsamında "uyarma" cezası bakımından belirtilen sakıncalar Yönetmelik m. 5-a için de geçerlidir. Burada da "yükseköğretim kurumu yetkilileri”nin kim ya da kimler olduğu belli olmadığı gibi, “istenilen bilgi”den ne anlaşılması gerektiği de açık değildir. Ancak söz konusu bilgi, yüksek öğretim kurumunun disiplin ve idaresi bakımından gerekli olan ve eksik ve yanlış bildirilmesinde bu açıdan sakınca bulunan bilgi olarak anlaşılmalıdır.

Yönetmelik m. 5-c'nin ilk hali "yükseköğretim kurumu içinde izinsiz afiş ve pankart asmak" şeklindeydi. Ancak "Yükseköğretim Kurumları Öğrenci Disiplin Yönetmeliğinde Değişiklik Yapılmasına Dair Yönetmelik"in 7.11.2013 tarihinde yürürlüğe girmesiyle birlikte mevcut halini almıştır. ${ }^{26}$ Bu kapsamda "Yükseköğretim Kurumları Öğrenci Disiplin Yönetmeliğinde Değişiklik Yapılmasına Dair Yönetmelik"in iptali istemiyle dava açılmış, Danıştay "yükseköğretim kurumu içinde izinsiz olarak bildiri dağıtmak" şeklinde öngörülen disiplin suçunun "Anayasaya ve Avrupa İnsan Hakları Sözleşmesi (AİHS) hükümlerine aykırı" olduğuna, nitekim bu suçla "düşünce ve ifade özgürlüğü”nü bağdaştırmanın mümkün olmadığına hükmetmiştir. ${ }^{27}$ Ayrıca Danıştay 8. Dairesi haklı olarak düşünce ve ifade özgürlüğüne getirilen bu sınırlandırmanın kanunla değil de Yönetmelikle gerçekleştirilmesine ve bildiri dağıtmanın idarenin iznine bağlanmak suretiyle keyfi uygulamalara neden olabileceğine vurgu yapmıştır. Bu kapsamda Danıştay 8. Dairesince söz konusu hükümle ilgili olarak yürütmenin durdurulmasına karar verilmiştir. Daha sonra yürütmenin durdurulması kararına ilişkin itiraz reddedilmişse de DİDDGK, Danıştay 8. Dairesỉnin düşünce ve ifade özgürlügüne getirilen bu sınırlandırmanın kanunla değil de Yönetmelikle gerçekleştirilmesinin hukuka aykırı olduğu yönündeki görüşünü eleştirmiş ve 2547 sayılı Kanun m. 54 ve m. 65/9-a ile genel çerçevesi çizilen disiplin suçlarının içeriğinin Yönetmelikle doldurulmasının mümkün

27 Danıştay 8. Dairesi ise 2013/11920 E. ve 30.4.2014 T. www.kazanci.com 2020. 
olduğuna hükmetmiştir. Böylelikle DİDDGK bir kez daha temel hak ve özgürlüklerden yana karar verme fırsatını kaçırmıştır.

Yönetmelik m. 5-d’de yer alan "sınavlarda kopyaya teşebbüs etmek" şeklindeki tanım da sorunludur. Aslında olması gereken, "sınavda kopyaya teşebbüs etmek”tir. Hükmün sadece lafzı esas alındığında tek bir sınavda kopyaya teşebbüs edilmesi halinde disiplin cezasının uygulanmaması gerekecektir. Aynı sorunlu ifade, Yönetmelik m. 7-e ve 8-d'de de kullanılmıştır. Söz konusu ifadeyle ilgili bir başka sorun da bir öğrencinin aynı sınav döneminde yahut aynı gün birden fazla sınavda kopya çekmesi halinde hakkında tek bir cezanın mı verileceği yoksa tekerrür hükümlerinin mi uygulanacağ konusundaki belirsizliktir.

\section{YÜKSEKÖĞRETIM KURUMUNDAN UZAKLAŞTIRMA CEZALARINI GEREKTIREN DISIPLIN SUÇLARI}

Yönetmelikte ilki, "bir haftadan bir aya kadar", ikincisi "bir yarıyıl için”, üçüncüsü ise "iki yarıyıl için” olmak üzere üç türlü “yükseköğretim kurumundan uzaklaştırma ceza”sı öngörülmüştür. "Yükseköğretim kurumundan bir haftadan bir aya kadar uzaklaştırma” cezası Yönetmelik m. 3-d uyarınca "öğrenciye, yükseköğretim kurumundan bir haftadan bir aya kadar uzaklaştırıldığının ve bu süre içerisinde derslere ve sınavlara katılamayacağının yazı ile bildirilmesi”dir. Yönetmelik m. 6’da bu disiplin cezasını gerektiren disiplin suçları yedi bent halinde sayılmıştır:

“a) Öğrenme ve öğretme hürriyetini engelleyici veya yükseköğretim kurumlarının işleyiş ve huzurunu bozucu eylemlerde bulunmak,

b) Disiplin soruşturmalarının sağlıklı bir şekilde yürütülmesini engellemek,

c) Yükseköğretim kurumundan aldığ 1 kendine hak sağlayan bir belgeyi başkasına vererek kullandırmak veya başkasına ait bir belgeyi kullanmak,

ç) Yükseköğretim kurumunda kişilerin şeref ve haysiyetini zedeleyen sözlü veya yazılı eylemlerde bulunmak,

d) Yükseköğretim kurumu personelinin, kurum içinde ya da dışında, şeref ve haysiyetini zedeleyen sözlü veya yazılı eylemlerde bulunmak,

e) Yükseköğretim kurumunda alkollü içki içmek,

f) Yükseköğretim kurumuna ait kapalı ve açık mahallerde yetkililerden izin almadan toplantılar düzenlemek."

"Ders, seminer, uygulama, laboratuvar, atölye çalışması, bilimsel toplantı ve konferans gibi çalışmaların düzenini bozma”nın Yönetmelik m. 5-b’de kınama cezasını gerektiren bir disiplin suçu olarak düzenlendiği belirtilmişti. Yönetmelik m. 6-a’ya göreyse “... yükseköğretim kurumlarının işleyiş ve huzurunu bozucu eylemlerde bulunmak" "yükseköğretim kurumundan bir haftadan 
bir aya kadar uzaklaştırma cezası”nı gerektirmektedir. Ancak bu iki hükmün birbirinden nasıl ayrılacağını gösteren ölçütlerin bulunmadığı görülmektedir. Bu nedenle aynı olayın hem m. 5 hem de m. 6 kapsamında değerlendirilmesi mümkündür. Dolayısıyla belirli bir fiil bir soruşturmacı tarafından $\mathrm{m}$. 5 kapsamında değerlendirilirken, başka bir soruşturmacı tarafından m. 6 kapsamında değerlendirilmeye müsaittir.

Yönetmelik m. 6-f'de yer alan "yükseköğretim kurumuna ait kapalı ve açık mahallerde yetkililerden izin almadan toplantılar düzenlemek" hükmü de bazı sorunları barındırmaktadır. Zira lafzi yorum yapıldığı takdirde örneğin, on öğrencinin kantinde bir araya gelerek okudukları bir kitabı tartışmak adına ya da kampüsün bahçesinde AİHS’te ve Anayasa’da öngörülen ifade özgürlügünü gerçekleştirmek amacıyla tümüyle barışçl nitelikte bir dans gösterisi yapmak üzere toplanmaları halinde bu hüküm uygulama alanı bulabilecektir.

"Yükseköğretim kurumundan bir yarıyıl için uzaklaştırma” cezası, Yönetmelik m. 3-e’de “öğrenciye, yükseköğretim kurumundan bir yarıyıl uzaklaştırıldığının ve bu sürede öğrencilik haklarından yararlanamayacağının yazı ile bildirilmesi” şeklinde tanımlanmıştır. Yönetmelik m. 7’deyse "yükseköğretim kurumundan bir yarıyıl için uzaklaştırma" cezasını gerektiren disiplin suçları sekiz bent halinde sayılmıştır:

“a) Yükseköğretim kurumu personeli ve öğrencilerini tehdit etmek,

b) Yükseköğretim kurumlarında işgal ve benzeri fiillerle yükseköğretim kurumunun hizmetlerini engelleyici eylemlerde bulunmak,

c) Kurum personeli ve öğrencilerine fiili saldırıda bulunmak,

ç) Yükseköğretim kurumlarında hırsızlık yapmak,

d) Yükseköğretim kurumu bünyesinde mevcut bina, demirbaş eşya ve benzeri malzemeyi tahrip etmek veya bilişim sistemine zarar vermek,

e) Sınavlarda kopya çekmek veya çektirmek,

f) Seminer, tez ve yayınlarında intihal yapmak.

g) Yükseköğretim kurumundan uzaklaştırma cezası almış olmasına rağmen, bu karara uymamak.”

Yönetmelik m. 3-g uyarınca "Yükseköğretim kurumundan iki yarıyıl için uzaklaştırma" cezası, "öğrenciye, yükseköğretim kurumundan iki yarıyıl uzaklaştırıldığının ve bu sürede öğrencilik haklarından yararlanamayacağının yazı ile bildirilmesi” şeklinde tanımlanmıştır. Yönetmelik m. 8'deyse "yükseköğretim kurumundan iki yarıyıl için uzaklaştırma" cezasını gerektiren disiplin suçları dokuz bent halinde sayılmıștır:

“a) Yükseköğretim kurumu görevlilerine karşı cebir ve şiddet kullanarak görevin yapılmasına engel olmak, 
b) Öğrencilere karşı cebir ve şiddet kullanarak yükseköğretim hizmetlerinden yararlanmalarını engellemek,

c) Bir kimseyi veya grubu, cebir veya tehditle suç sayılan bir eylemi düzenlemeye veya böyle bir eyleme katılmaya zorlamak,

ç) Yükseköğretim kurumları içerisinde uyuşturucu ve uyarıcı madde kullanmak, taşımak, bulundurmak,

d) Sınavlarda tehditle kopya çekmek, kopya çeken öğrencilerin sınav salonundan çıkarılmasına engel olmak, kendi yerine başkasını sınava sokmak veya başkasının yerine sınava girmek,

e) Yükseköğretim kurumlarında cinsel tacizde bulunmak,

f) Yükseköğretim kurumlarında 10/7/1953 tarihli ve 6136 sayılı Ateşli Silahlar ve Bıçaklar ile Diğger Aletler Hakkında Kanuna aykııı olarak ateşli silahlarla mermilerini ve bıçaklarla saldırı ve savunmada kullanılmak üzere özel olarak yapılmış bulunan diğer aletleri, patlayıcı maddeleri taşımak ve bulundurmak,

g) Yükseköğretim kurumunun bilişim sistemine girerek kendisine veya başkasının yararına haksız bir çıkar sağlamak.

ğ) Soruşturma ile görevlendirilenleri tehdit etmek.”

Söz konusu hükmün yürürlüğe girmesinin ardından 18.8.2012 tarihinde yürürlüğe giren "Yükseköğretim Kurumları Öğrenci Disiplin Yönetmeliğinde Değişiklik Yapılmasına Dair Yönetmelik" ${ }^{28}$ m. 2 ile (c) bendine "suç sayılan eylemleri işlemek" ifadesi eklenmiştir. Ancak bu ifadenin düzenleyici bir işlemde bulunması gereken "açı ve belirgin" olma koşulunu taşımaması ve bu belirsizliğin öğrencilerin eğitim ve öğrenim hakkı üzerinde doğurabileceği sonuç dikkate alındığında hukuka aykırı olduğu belirtilerek yürütmenin durdurulmasına karar verilmiştir. ${ }^{29}$ Sonrasındaysa Danıştay bu ifadeyi iptal etmiştir. ${ }^{30}$

"Yükseköğretim kurumundan bir haftadan bir aya kadar uzaklaştırma" cezası bakımından dönemlik ya da ylllık ders veren bir fakültede verilen bir aylık disiplin cezası neticesinde örneğin öğrencinin final ve bütünleme sınavlarına girememesi nedeniyle, bir anlamda söz konusu cezanın adeta yükseköğretim kurumundan dönemlik ders veren fakültelerden bir yarıyıl uzaklaştırma, yıllık ders veren fakülteler bakımındansa iki yarıyıl için uzaklaştırma cezası anlamına gelebilecek nitelikte sonuç doğurması mümkündür. Yine devamın zorunlu olduğu fakülteler bakımından öğrencinin devamsızlı yüzünden kalması nedeniyle de aynı yorumu yapmak mümkündür. Böylece söz konusu cezanın sonuç olarak bir üst ve hatta iki üst cezaya dönüşmesi şeklinde bir tehlikeyi bünyesinde barındırdığı belirtilmelidir.

\footnotetext{
2828814 sayılı Resmî Gazete.

29 DİDDGK 2014/843 E. 3.11.2014 T. www.kazanci.com, 2020.

30 Danıştay 8. Dairesinin 2013/11920 E. 2018/7538 K. ve 29/11/2018 T. www.mevzuat.gov.tr 2020
} 
Aynı sorun, "yükseköğretim kurumundan bir yarıyıl için uzaklaştırma" cezası bakımından da gündeme gelmektedir. Nitekim dönemlik ya da yıllık dersleri olan bir fakültede öğrenim gören bir öğrencinin ikinci yarıyılın başlangıcında bu cezayı alması öğrencinin okulunu iki yarıyıl uzatmasına neden olacaktır. Yıllık dersleri olan fakültedeki öğrencinin birinci yarıyılın başlangıcında bu cezayı alması halindeyse ikinci yarıyılda kayıt yenilemesi gereken dönemde bu dersleri alamaması da yine iki yarıyıl dönemini uzatmasına sebebiyet verecektir. Bu nedenle söz konusu ceza, sadece dönemlik dersleri olan fakültedeki öğrenci bakımından birinci yarıyılın başlangıcında bu cezayı alması halinde gerçekten "bir yarıyıl için uzaklaştırma” cezası anlamını taşıyacaktır. Bu durumsa aynı fiili işleyen iki öğrencinin birinin derslerinin dönemlik, diğerininse yıllık olması halinde haklarında aynı disiplin cezası uygulanmasına rağmen farklı sonuçların doğmasına yol açacak ve eşitlik ilkesi açısından sakıncalar doğuracaktır.

Benzer sorun, "yükseköğretim kurumundan iki yarıyıl için uzaklaştırma” cezası bakımından da söz konusudur. Öğrencinin dersleri yıllık olan bir fakültede öğrenim görmesi halinde, ikinci yarıyılın başından itibaren bu cezayı alması, aslında okulunu üç yarıyıl uzatmasına sebebiyet verebilecek niteliktedir. Bu durumun disiplin cezaları bakımından geçerli olan kanunilik ilkesini ihlal ettiği söylenebilir. Zira Yönetmelikte üç yarıyıl için uzaklaştırma cezası öngörülmemiştir. Nitekim daha evvel de belirtildiği üzere Yönetmelik m. 10. uyarınca uyarma ve kınama cezasını gerektiren disiplin suçları bakımından kıyasa yer verilmiş olmasına karşın diğer cezaları gerektiren disiplin suçları bakımından böylesine bir düzenlemeye yer verilmemesi, kanunilik ilkesine bağlı kalındığını göstermektedir. Dolayısıyla ilgili hükümler kanunilik ilkesi açısından ele alındığında önemli sorunlar içermektedir.

Üç tür uzaklaştırma cezası bakımından da cezanın uygulanmasına ne zaman başlanacağının açıkça öngörülmemiş olması, açıklandığı üzere, uygulamada farklı sonuçların doğmasına neden olabilecek niteliktedir. Yönetmelik m. 25 “disiplin cezası vermeye yetkili amir veya kurul kararlarında hangi tarihten itibaren uygulanacağı belirtilmediği takdirde, disiplin cezaları verildikleri tarihten itibaren uygulanırlar” şeklindedir. Yönetmelikte yapılacak bir değişiklikle bu durumun açıklığa kavuşturulmasında fayda vardır. Söz konusu değişiklik, ilgili uzaklaştırma cezasının izleyen yarıyıl için uygulanması şeklinde olmalıdır.

Buna karşın Yönetmelik m. 25’teki düzenlemenin iptali istemiyle ilgili olarak açılan davada Danıştay uygulamada cezanın uygulanma tarihi ile ilgili meydana gelebilecek ihtilafların açılacak davada değerlendirilebileceği gerekçesiyle anılan düzenlemede hukuka aykırılık görmemiştir. ${ }^{31} \mathrm{Bu}$ karara karşı yapılan temyiz başvurusu sonucunda DİDDGK kararı onamıştır. ${ }^{32}$

31 Danıştay 8. Dairesi, 2012/9483 E. 2016/4594 K. ve 09/05/2016 T. www.kazanci.com.

32 DİDDGK 2016/4019 E. 2017/1660 K. ve 19.4.2017 T. www.kazanci.com 2020. 


\section{E. YÜKSEKÖĞRETIM KURUMUNDAN ÇIKARMA CEZASINI GEREKTIREN DISIPLIN SUÇLARI}

“Yükseköğretim kurumundan çıkarma” cezası Yönetmelik m. 3-f’de “öğrenciye, bir daha çıkarıldığ yükseköğretim kurumuna alınmamak üzere öğrencilikten çıkarıldığının yazı ile bildirilmesi” şeklinde tanımlanmıştır. 2547 sayılı Kanun m. 54-g’nin “yükseköğretim kurumundan çıkarma cezası verilen öğrenciler, bir daha herhangi başka bir yükseköğretim kurumuna alınamazlar” şeklindeki 2. cümlesi, Anayasa m. 42'de öngörülen ve temel bir hak olan eğitim ve öğrenim hakkından yararlanmayı imkansız hale getirmek suretiyle Anayasa m. 13'de düzenlenen hakkın özüne dokunma yasağına aykırı olduğu gerekçesi ile AYM tarafından iptal edilmiştir. ${ }^{33}$ AYM’nin söz konusu iptal kararından evvel iptal davasına konu olan bu hükümle ilgili olarak DİDDGK’nin kimsenin eğitim ve öğrenim hakkından yoksun bırakılamayacağını düzenleyen Anayasanın 42. maddesinin 1. fıkrasına aykırılık oluşturmadığı görüşünde olduğu belirtilmelidir. ${ }^{34}$

Yönetmelik m. 3-ç’de yükseköğretim kurumları, “üniversiteler, yüksek teknoloji enstitüleri ile bunların bünyesinde yer alan fakülteler, enstitüler, yüksekokullar, konservatuvarlar, meslek yüksekokulları ile uygulama ve araştırma merkezleri” şeklinde tanımlanmıştır. Buna göre örneğin hukuk fakültesinde öğrenim görmekte olan bir öğrenci hakkında "yükseköğretim kurumundan çıkarma cezası” verildiğinde, öğrenci tekrar sınava girerek aynı üniversitenin hukuk fakültesini kazandığında, AYM’nin anılan iptal kararına konu olan hükümde "herhangi başka bir yükseköğretim kurumuna" alınamamadan bahsedildiğinden, öğrencinin tekrar bu fakülteye kaydını yaptıramayacağı anlaşılmaktadır. Ancak yükseköğretim kurumunun tanımından hareket edildiğinde bu tanımın hem Üniversiteleri hem de bunların bünyesinde yer alan fakülteleri ifade etmesi karşısında, söz konusu öğrencinin aynı üniversitenin başka bir fakültesini kazanması halinde de uygulanıp uygulanmayacağı ve kayıt yaptırıp yaptıramayacağı belli değildir.

Yönetmelik m. 9'da "Yükseköğretim kurumundan çıkarma” cezasını gerektiren disiplin suçları 4 bent halinde olmak üzere aşağıdaki şekilde sayılmıştır:

“a) Mahkeme kararıyla kesinleşmiş olmak kaydıyla, suç işlemek amacıyla örgüt kurmak, böyle bir örgütü yönetmek veya bu amaçla kurulan örgüte üye olmak, üye olmamakla birlikte örgüt adına faaliyette bulunmak veya yardım etmek,

b) Yükseköğretim kurumlarında uyuşturucu veya uyarıcı maddeleri satmak, satın almak, başkalarına vermek ve ticaretini yapmak,

c) 6136 sayılı Ateşli Silahlar ve Bıçaklar ile Diğer Aletler Hakkında Kanuna aykırı olarak ateşli silahlarla, mermilerini ve bıçaklarla saldırı ve savunmada kullanılmak üzere özel olarak yapılmış bulunan diğer aletleri, patlayıcı maddeleri kullanmak,

33 AYM, E. 2009/59, K. 2011/69, T. 28/4/2011 (Karar metni için bkz. 27992 sayılı 12.7.2011 tarihli Resmî Gazete.

34 DİDDGK 1998/866 E. 1999/329 K. 26.2.1999 T. www.kazanci.com, 2020 
ç) Kişilerin vücudu üzerinde cinsel davranışlarda bulunmak suretiyle cinsel dokunulmazlıklarını ihlal etmek."

Belirtmek gerekir ki (a) bendindeki tanım belirgin değildir. Ancak burada soruşturulan öğrencinin bentte sayılan fiiller nedeniyle hakkında kesinleşmiş bir mahkûmiyet hükmünün bulunması aranmalıdır. Nitekim “...davacının suç işlemek amacıyla örgüt kurmak, böyle bir örgütü yönetmek veya bu amaçla kurulan örgüte üye olmak, üye olmamakla birlikte örgüt adına faaliyette bulunmak veya yardım etmek fiillerinden herhangi birini ya da hepsini işlediğine veya bu yönde eylemde/ faaliyette bulunduğuna dair işlem tarihinden önce adli yargı mahkemelerince verilen kesinleşmiş bir karar bulunma”sını arayan Danıştay’ın da bu görüşte olduğu görülmektedir. ${ }^{35}$ Yine aynı doğrultudaki bir başka kararında Danıştay “...davacı hakkında, terör örgütlerine veya Milli Güvenlik Kurulunca Devletin milli güvenliğine karşı faaliyette bulunduğuna karar verilen yapı, oluşum veya gruplara üyeliği, mensubiyeti veya iltisakı yahut bunlarla irtibatı olduğuna dair adli yargı mahkemelerince verilen kesinleşmiş bir mahkumiyet hükmü bulunma”sını aramaktadır. ${ }^{36}$

Uygulamada herhangi bir karışıklığa mahal bırakmamak amacıyla söz konusu bende "mahkeme kararıyla mahkûmiyet hükmünün kesinleşmiş olması kaydıyla” ifadesi eklenmelidir. Henüz böyle bir kesinleşme yokken bu disiplin cezası uygulanamayacağı gibi, öğrencinin söz konusu suçu işlediği sabit olmasına karşın hakkında hükmün açıklanmasının geri bırakılması kararı verilmesi halinde de bu disiplin cezasının uygulanması mümkün olmaz. Zira soruşturulan öğrenci hakkında ceza mahkemesince hükmün açıklanmasının geri bırakılmasına karar verildiği takdirde her ne kadar suçu işlediği sabit olsa da bu mahkûmiyet hükmü açıklanmadığından ve de kesinleşmediğinden Yönetmelik m. 9-a’nın uygulanması koşulları sağlanmış olmayacaktır. Bu nedenle soruşturulanın durumunun 5271 sayılı Ceza Muhakemesi Kanunu'nun (CMK) m. 231/11 uyarınca denetim süresi içinde kasten yeni bir suç işlemesi veya denetimli serbestlik tedbirine ilişkin yükümlülüklere aykırı davranması halinde, mahkeme hükmü açıkladığı takdirde tekrar değerlendirme hususu saklı kalmak kaydıyla soruşturulan hakkında herhangi bir disiplin cezası verilmemesi gerekmektedir.

Öğrenci hakkında TCK m. 51 uyarınca hapis cezasının ertelenmesine karar verilmişse artık söz konusu maddenin 8. fikrası uyarınca "denetim süresi yükümlülüklere uygun veya iyi halli olarak geçirildiği takdirde, ceza infaz edilmiş" sayılacağından artık öğrenci hakkında aynı zamanda ceza hukuku anlamında da suç oluşturan fiili nedeniyle disiplin cezası verilmesi mümkündür.

Söz konusu fiilin öğrencilik sıfatı başlamadan önce gerçekleştirilmesi, ancak mahkumiyet hükmünün öğrencilik sıfatının başlamasından sonra kesinleşmesi halinde, bu cezanın uygulanıp uygulanmayacağı konusunda tereddüt edilebilir. Ancak disiplin hükümleri, daha önce de belirtildiği üzere, kişinin içinde bulunduğu hukuki statü nedeniyle tabi olduğu kurallardır ve bu statünün başlamasından önce ya da bitmesinden sonra kişiye uygulanmazlar. Dolayısıyla bu gibi durumlar bakımından öğrencilik statüsünün sonlandırılması isteniyorsa, bu yönde açık düzenlemenin yapılması gerekir.

35 Danıştay 8. Daire 2019/10267 E. 2020/3565 K. 16.9.2020 T. http://emsal.danistay.uyap.gov.tr/, 2021.

36 Danıştay 8. Daire 2019/4898 E. 2019/6635 K. 4.7.2019 T. www.kazanci.com, 2020. 
Yönetmeliğin "Disiplin suçunun tekerrürü" başlığını taşıyan 11. maddesindeyse, şayet öğrenci tarafından hakkında disiplin cezası verilmesine sebep olan fiil tekrar işlenmişse, öğrenci hakkında "bir derece ağır" cezanın uygulanacağı belirtilmiştir. Öte yandan tekerrür halinde verilecek bu cezanın hiçbir şekilde "yükseköğretim kurumundan çıkarma cezası" olamayacağı düzenleme altına alınmıştır.

\section{F. YÜKSEKÖĞRETIM KURUMU ÖĞRENCI DISIPLIN SORUŞTURMASI USULÜNE ILIŞKIN DEĞERLENDIRMELER}

2547 sayılı Kanun ve Yönetmelik yalnızca disiplin suçları ve cezalarına ilişkin hükümler açısından değil, aynı zamanda öğrencilerin disiplin yönünden soruşturulmalarına ilişkin usulü düzenleyen maddeler yönünden de eleştiriye açıktır. Söz gelimi, Yönetmelik m. 13/1 uyarınca soruşturmaya "disiplin soruşturmasına konu olayın öğrenilmesini müteakip derhal başlanır. Soruşturma, onay tarihinden itibaren on beş gün içinde sonuçlandırılır". Bununla beraber uygulamada çoğunlukla bu süreye uyulmadığı ve uyulmasının da mümkün olmadığı görülmektedir. Esasında Yönetmeliğin yürürlüğe girdiği ilk şeklinde söz konusu düzenleme, soruşturmanın bu süre içerisinde bitirilememesi halinde soruşturmacının gerekçeli olarak ek süre verilmesi talebinde bulunacağı; soruşturma açmaya yetkili disiplin amirinin uygun bulması halinde soruşturma süresini uzatabileceği yönündeydi. Ancak Danıştay söz konusu cümleleri 2547 sayılı Kanun m. 54-c’de disiplin soruşturmasına olay öğrenilince derhal başlanılacağı ve soruşturmanın en geç on beş gün içinde sonuçlandırılacağının kurala bağlandığı, soruşturmacıya ek süre verilmesine imkân tanıyan bir düzenlemeye ise yer verilmediği, bu haliyle, soruşturma açmaya yetkili disiplin amirine soruşturma süresini uzatabilme yetkisi veren bu düzenlemenin üst hukuk normu olan yasaya aykırı olduğu gerekçesiyle iptaline karar vermiştir. ${ }^{37}$

Ancak tebligat sorunları nedeniyle öğrencilere ulaşılamaması veya Yönetmelik m. 15 uyarınca öğrenciye en az yedi günlük savunma süresi tanıma zorunluluğu gibi hususlar göz önüne alındığında, söz konusu iptal kararı sonucunda ortaya çıkan yeni durumun içinden çıkılması zor çelişkiler yarattığı ortadadır. Gerçekten de ya süre şartına uyulması amacıyla etkin bir disiplin soruşturma gerçekleştirilemeyecek ya da etkin bir soruşturma gerçekleştirmek amacıyla süre şartına uyulamayacaktır. Ancak her iki durumda da disiplin cezasına ilişkin hükmün iptali riski söz konusudur. Bilindiği üzere, etkin bir soruşturmanın yapılması yalnızca hakkında soruşturma açılan öğrenciye savunma hakkının tanınmasından ibaret değildir. Soruşturma konusu olayın bir disiplin suçunu oluşturup oluşturmadığının ve hakkında soruşturma başlatılan öğrenci tarafından işlenip işlenmediğinin tespit edilebilmesi için gerekli tüm araştırmaların yapılması şarttır. $\mathrm{Bu}$ nedenle etkin bir soruşturma gerçekleştirmek amacıyla süre şartına uyulamayabilir. Nitekim Danıştay'ın yaklaşımının da bu şekilde olduğu görülmektedir. Buna göre, disiplin cezası vermeye yetkili mercilerce suç sayılacak eylemlerin işlendiğinin öğrenilmesi halinde bu öğrenciler hakkında soruşturma emri verilerek, soruşturmacı görevlendirilerek başlatılacak soruşturmada varsa iddia sahipleri ile tanık ve sanık ifadeleri alınarak gerekli araştırma ve inceleme ile soruşturma sonucunda

37 Danıştay 8. Dairesi, 2012/9483 E., 2016/4594 K. ve 09/05/2016; DİDDGK 2016/4019 E. 2017/1660 K. ve 19.4.2017 www. kazanci.com 2020. 
olayın değerlendirilmesi adli, idari ve disiplin yönünden sanık öğrenci hakkında soruşturmacı kanaat ve teklifinin de yer aldığı soruşturma raporunun hazırlanması, olayın şüpheye yer verilmeyecek şekilde somut delillerle ortaya konulmuş olması, öğrenci hakkında isnat edilen suç konusu eylem, işlem, tutum ve davranışların tek tek bildirilerek savunmasının alınması ve bunlardan sonra yetkili amir ve kurullarca bilgi ve belgelerin bulunduğu soruşturma dosyasının incelenerek karar verilmesi gerekmektedir. Ancak güvenlik görevlilerince düzenlenen tutanak üzerine soruşturma açıldığı ancak iddia edilen olaylar tek tek araştırılarak, görgü tanıklarının ifadelerine yer verilerek iddia edilen disiplin suçunun açı ve net olarak somut olaylar ile tereddüte yer birakmayacak şekilde ortaya konulması gerekirken, sadece tutanaktaki güvenlik görevlilerinin ve davacı öğrencinin ifadesi alınarak soruşturma raporunun düzenlendiği ve buna dayanılarak disiplin cezası verilen olayda Danıştay hukuka uyarlık bulunmadığına karar vermiştir. ${ }^{38}$

Danıştay kararlarında soruşturmanın on beş günlük süreyi aşacak şekilde bitirilmesinin disiplin cezasının iptalini gerektirmediğini kabul etmektedir. Danıştay’a göre, bu süre; idarenin iç işleyişiyle ilgili olup delillerin kaybolmasını önlemek, soruşturmanın daha çabuk yapılarak disiplin suçunu işlemiş olan kişiye daha etkin ve daha çabuk ceza verilmesini sağlamak amacı ile konulmuştur. Dolayısıyla Danıştay, soruşturmanın bu süre içerisinde bitirilmemesinin, disiplin suçunu işleyen kişi yönünden artık ceza verilemeyeceği gibi bir hak doğuramayacağını; ancak görevliler yönünden bir sorumluluğu gerektirebileceğini belirtmiştir. Danıştay, Yönetmelik m. 34’ün son fikrasında disiplin cezasını gerektiren fiil ve hallerin işlendiği tarihten itibaren iki yıl içinde disiplin cezası verilmediği takdirde ceza verme yetkisinin zamanaşımına uğrayacağının kurala bağlanmış olması karşısında, soruşturmanın on beş gün içerisinde bitirilmemesinin disiplin suçunun zamanaşımına uğraması sonucunu doğurmayacağına hükmetmiştir. ${ }^{39}$

7.11.2013 tarihinde yürürlüğe giren "Yükseköğretim Kurumları Öğrenci Disiplin Yönetmeliğinde Değişiklik Yapılmasına Dair Yönetmelik'in ${ }^{40}$ 3. maddesiyle "Yükseköğretim Kurumları Öğrenci Disiplin Yönetmeliğ̣i"nin 14. maddesinin 6. fikrasına "soruşturmacılar; zaruri gördükleri takdirde soruşturma süresince, soruşturulan öğrencilerin yükseköğretim kurumu binalarına girmesinin yasaklanması hususunda karar verilmesini disiplin soruşturmasını açmaya yetkili merciden isteyebilirler” şeklindeki hüküm eklenmiştir. Danıştay 8. Dairesi, bu hüküm bakımından yerinde olarak hakkında isnat edilen disiplin suçunu işlediği sabit olmayan bir öğrencinin henüz soruşturma süreci içinde söz konusu işleme tabi tutulmasının temel hak niteliğinde olan eğitim hakkını ihlal ettiğini belirterek yürütmenin durdurulmasına karar vermiştir. ${ }^{41}$

2547 sayılı Kanun m. 54-b’ye göre "bir fakülte, enstitü veya yüksekokulun içinde veya dışında öğrencilerin işlemiş oldukları disiplin suçlarından dolayı soruşturma yapmaya ve doğrudan gerekli cezayı vermeye veya disiplin kuruluna sevketmeye ilgili fakülte dekanı, enstitü veya yüksekokul

38 Danıştay 8. Daire 2004/2193 E. 2004/3624 K. 5.10.2004 T. www.kazanci.com, 2020.

39 Danıştay 8. Dairesi, T: 22.04.1987, E: 1985/737 E. 1987/204 K. 22.4.1987 T. GÜRER, Onur:, Danıştay Kararları Işığında Öğrencilere Verilen Disiplin Cezalarının Yargısal Denetim, İstanbul Üniversitesi Sosyal Bilimler Enstitüsü Kamu Hukuku Anabilim Dalı, Yayınlanmamış Yüksek Lisans Tezi, İstanbul 2010, s. 97-98.

4028814 sayılı Resmî Gazete.

41 Danıştay 8. Daire E. 2013/11920 T. 30.4.2014 www.kazanci.com, 2020. 
müdürü yetkilidir." Buna karşın "Soruşturma Açmaya Yetkili Amirler" başlığını taşıyan Yönetmelik m. 12/1-d'de "müşterek alan veya mekanlarda toplu öğrenci eylemleri ile ilgili olarak üniversite rektörleri”nin yetkili olduğundan bahsedilmiştir. "Soruşturmanın Sonuçlandırılması” başlıklı Yönetmelik m. 18/2'de "müşterek mekanlarda işlenen disiplin suçlarından dolayı uyarma, kınama ve yükseköğretim kurumlarından bir aya kadar uzaklaştırma cezası verme yetkisi”nin "rektöre ait" olduğu, f. 4’te "rektörlük tarafından yürütülen soruşturmalarda ise üniversite yönetim kurulu disiplin kurulu"nun yetkili olduğu kabul edilmiştir. Rektöre ve üniversite yönetim kuruluna verilen bu yetkilerin 2547 sayılı Kanun’a aykırı olduğu gerekçesiyle iptali istenmişse de Danıştay 8. Dairesi, "üniversite içerisinde, müşterek alanlarda, farklı fakülte ve yüksekokul öğrencilerinin karıştğ̆ı öğrenci olaylarına ilişkin uygulamada yaşanan sorunları gidermek açısından, bu tür toplu öğrenci eylemleri ile ilgili olarak üniversite rektörlerine soruşturma açma ve disiplin cezası verme yetkisi verilmesinde hukuka aykırılık bulunmadığı”na hükmetmiștir. ${ }^{42}$ DİDDGK ise, söz konusu düzenlemelerin üst hukuk kuralına ve bu kapsamda normlar hiyerarşisine açıkça aykırı olduğunu, nitekim 2547 sayılı Kanun'da rektörlere ve üniversite yönetim kuruluna bu şekilde bir yetki verilmemesine karşın Yönetmelikle bu yetkinin verilmesinin kanuna aykırı olduğu belirterek Danıştay 8. Dairesi’nin kararını bozmuştur. ${ }^{43}$ Buna karşın Yönetmeliğe bakıldığında bu hükmün halen yürürlükte olduğu görülmektedir. Ancak söz konusu durumun yerinde olmadığı zira müșterek alanlarda gerçekleştirilen disiplin suçları bakımından nasıl hareket edileceği bakımından tereddüde neden olduğu belirtilmelidir.

Yönetmelik m. 13/3'ün "ancak, disiplin amir veya kurulunun, bir adli yargı hükmüne ihtiyaç duyduğu hallerde; zamanaşımı süresi adli yargı hükmünün kesinleştiği günden itibaren başlar. Söz konusu ihtiyaç, yetkili disiplin amir veya kurulunun alacağı bir karar ile tespit edilir" şeklindeki son iki cümlesiyle ilgili olarak iptal isteminde bulunulmuş, Danıştay ise "adli bir olay olması nedeniyle, ceza yargılaması devam eden eylemlere dair verilen disiplin cezaları hakkında yargı organlarınca ceza mahkemesi kararının beklenmesi gerektiği yönündeki kararlar sebebiyle uygulamada yaşanan sıkıntıların giderilmesi amacıyla tesis edildiği anlaşılan, bu düzenlemelerde" herhangi bir hukuka aykırılığın bulunmadığına hükmetmiştir. ${ }^{44}$ Yapılan temyiz başvurusu üzerine DİDDGK zamanaşımı süresinin kamu düzenine ilişkin olması karşısında söz konusu durumun bir adli yargı hükmünün kesinleşmesine bağlandığını ve bu bağlanmanın da yetkili disiplin amiri ya da kuruluna bırakıldığını belirterek ayrıca hangi olaylar bakımından adli yargı hükmünün kesinleşmesinin bekleneceğine ilişkin herhangi bir ölçütün bulunmamasını ve bunun tümüyle disiplin amirinin veya kurulunun takdirine bırakılmasının kamu yararına aykırılık oluşturduğunu ve de bu hükmün Yönetmeliğin "ceza kovuşturması ile disiplin soruşturmasının bir arada yürütülmesi” başlığını taşıyan ve "aynı olaydan dolayı, öğrenci hakkında ceza kovuşturmasının başlamış olması, disiplin soruşturmasını geciktirmez. Öğrenci hakkında ceza kovuşturması açılmış olması, kanuna göre mahkûm olması veya

42 Danıştay 8. Dairesi, 2012/9483 E. 2016/4594 K. ve 09/05/2016 T. www.kazanci.com, 2020.

43 DİDDGK 2016/4019 E. 2017/1660 K. ve 19.4.2017 T. www.kazanci.com, 2020.

44 Danıştay 8. Daire 2012/9483 E. 2016/4594 K. ve 09/05/2016 T. www.kazanci.com 2020. 
olmaması disiplin cezasının verilmesine engel teşkil etmez" şeklinde hükme bağlanan 17. maddesiyle çeliştiğini belirterek Danıştay 8. Dairesi'nin bu kararını bozmuştur. ${ }^{45}$

Yönetmelik m. 13/3’ün de halen yürürlükte olduğu görülmektedir. Hukuk fakültesi mezunu öğretim elemanları tarafından gerçekleştirilen soruşturmalarda dahi Yönetmelikle ilgili söz konusu Danıştay kararlarının takibi güçken ve mevzuatın en güncel haline erişmek için kullanılan internet sitelerinde bu kararlar çoğu zaman bulunmazken, hukuk fakültesi mezunu olmayan öğretim elemanlarınca yükseköğretim kurumu öğrencileri hakkında disiplin soruşturmasının yürütülmesinin oldukça zor olduğu belirtilmelidir.

Yukarıda değinilen Yönetmelik m. 17 hükmü, esasında ceza hukuku yaptırımlarıyla disiplin cezalarının farklı hukuki varlık veya menfaatleri korumayı amaçlamasından kaynaklanmaktadır. ${ }^{46} \mathrm{Bu}$ nedenle disiplin cezalarıyla ceza hukuku anlamındaki cezalar, amaçları ve veriliş usulleri bakımından birbirlerinden ayrıdır. ${ }^{47}$ Ceza hukuku anlamındaki cezalarla toplumsal düzene aykırı davranışlar; disiplin cezalarıylaysa da bir kurumun düzenine aykırı davranışlar cezalandırılmaktadır. ${ }^{48} \mathrm{Bu}$ kapsamda mülga Yükseköğretim Kurumları Öğrenci Disiplin Yönetmeliğinin uygulanmasıyla ilgili olarak Danıştay’ın görüşünün de aynı doğrultuda olduğu anlaşılmaktadır. ${ }^{49}$

Yükseköğretim kurumu öğrencileri hakkında disiplin soruşturması yapılması ve ceza verilmesi bakımından önemli bir husus da sürecin kısa olmasının gerekmesidir. Aksi halde bazı önemli sorunlar ortaya çıkabilecektir. Örneğin son sınıftaki bir öğrenciye yıl sonuna yakın bir zamanda işlediği disiplin suçu nedeniyle "yükseköğretim kurumundan uzaklaştırma” ya da "çıkarma” cezası verilmesi halinde cezanın uygulanabilirliği ve kendisinden beklenen işlevi yerine getirmesi şüpheli hale gelir. Zira mezun olan bir öğrenciye bu statünün sona ermesinin ardından geçerli olacak şekilde verilen disiplin cezası geçmişe yürümeyecek ve öğrencinin mezuniyetine ilişkin statüsünü ortadan kaldırmayacaktır. Öğrencinin hem disiplin hem de ceza hukuku anlamında suç oluşturan davranışı nedeniyle hakkında ceza mahkemesince verilen mahkûmiyet hükmünün kesinleşmesinin aranması, fiilen öğrenci hakkında disiplin cezasının verilememesine yol açabilir. Bu durum, disiplin cezalarının uygulanmasının temel amacı olan kurum içinde bozulan düzenin bir an evvel ve gecikmeksizin tesisine engel olabilir. ${ }^{50}$ Öte yandan Yönetmelik m. 17 bazı önemli sorunlara yol açabilir. Nitekim kimi hallerde ve özellikle de “yükseköğretim kurumundan uzaklaştırma” ve "yükseköğretim kurumundan çıkarma” cezaları bakımından öğrencinin işlediği fiil aynı zamanda suç oluşturuyorsa, ceza muhakemesinin sonucunu beklemek daha doğru olacaktır. Zira böylece maddi gerçeğe uygun bir disiplin cezasının verilmesi mümkün olabilir. Aksi halde öğrenci hakkında verilen disiplin cezası sonradan iptal edilse dahi telafisi güç zararların doğması mümkündür. ${ }^{51} \mathrm{Bu}$

45 DİDDGK 2016/4019 E. 2017/1660 K. ve 19.4.2017 T. www.kazanci.com 2020.

46 TORTOP, Nuri: “Disiplin, Disiplin Cezaları ve Disiplin Suçları”, Amme İdaresi Dergisi (1983), Cilt 16, sayı 3, ss. 89-100, s. 90 .

47 GÜNDAY, Metin: İdare Hukuku, İmaj Yayınevi, Ankara, 2013, s. 628.

48 GÖZÜBÜYÜK, Şeref: Yönetim Hukuku, “S” Yayınları, Ankara, 1991, 151.

49 Danıştay 8. Dairesi 2003/534 E. 2003/3075 K. ve 23.6.2003 T. www.kazanci.com, 2020.

50 ULUSOY, s. 152, 173-174.

51 OĞURLU, s. 113. 
nedenle Yönetmelikte özellikle "yükseköğretim kurumundan uzaklaştırma" ve de "çıarma" cezaları bakımından öğrencinin işlediği fiilin aynı zamanda suç oluşturması halinde "mahkeme kararıyla mahkûmiyet hükmünün kesinleşmiş olması kaydıyla" ifadesinin eklenmesinde fayda vardır. $\mathrm{Bu}$ kapsamda önemle vurgulamak gerekir ki CMK m. 223/2-a uyarınca "yüklenen fiilin kanunda suç olarak tanımlanmamış olması, yüklenen suçun sanık tarafından işlenmediğinin sabit olması, yüklenen suç açısından failin kast veya taksirinin bulunmaması, yüklenen suçun sanık tarafından işlenmesine rağmen, olayda bir hukuka uygunluk nedeninin bulunması, yüklenen suçun sanık tarafından işlendiğinin sabit olmaması," nedeniyle öğrenci hakkında verilen beraat kararı öğrenci hakkında disiplin cezasının verilmesine engel olmalıdır. Ancak burada dikkatli olunmalıdır. Nitekim artık öğrencinin davranışı suç oluşturmasa da örneğin kıyasın mümkün olduğu "uyarma" ya da "kınama" cezasını gerektiren disiplin suçlarını oluşturuyorsa hakkında bu cezalara hükmedilebilir. Örneğin öğrencinin "yükseköğretim kurumundan iki yarıyıl için uzaklaştırma cezasını gerektiren" "sınavlarda tehditle kopya çekmek" fiilini işlediği iddiasıyla ilgili olarak öğrenci hakkında tehdit suçundan dolayı gerçekleştirilen yargılamada beraat kararı verilmişse bu hüküm öğrenci hakkında söz konusu disiplin cezasının verilmesine engel oluştursa da gerçekleştirilen disiplin soruşturması neticesinde öğrencinin kopya çektiği sabitse, hakkında Yönetmelik m. 7 uyarınca "yükseköğretim kurumundan bir yarıyıl için uzaklaştırma cezasını gerektiren" "sınavlarda kopya çekmek" disiplin suçundan dolayı ceza verilmesi mümkündür. Bu kapsamda öğrenci hakkında hem disiplin suçunu hem de ceza hukuku anlamında bir suçu oluşturan fiili nedeniyle CMK m. 223 uyarınca, mahkûmiyet hükmünün dışında "ceza verilmesine yer olmadığı", "güvenlik tedbirine hükmedilmesi", "davanın reddi” ve "düşmesi kararı" verilmişse öğrenci hakkında disiplin cezasının verilmesinin mümkün olduğu kabul edilmelidir.

\section{SONUÇ}

İdari müeyyideler, ceza hukuku müeyyideleri gibi, çoğunlukla temel hak ve özgürlüklerle yakından ilişkilidir. İdari müeyyidelerin bir türü olan disiplin cezaları ise, bu bağlamda özel bir önem arz etmektedir. Bir statüye dahil olmanın mahiyetinden doğan ve idarenin bireyler üzerinde idari müeyyide uygulama yetkisinin birer yansıması olan disiplin cezalarının ceza hukuku anlamındaki cezalara nazaran daha hafif olduğu kanısı, doğurdukları önemli sonuçlar göz önüne alındığında çoğu zaman doğru sayılmaz. Yükseköğretim kurumunun iç çalışma düzenini, başka bir deyişle idari düzenini korumak ve yürütülen hizmetin düzgün işlemesini sağlamak amacıyla, yükseköğretim kurumu yönetimlerince bu kurumdan hizmet alanlar, yani öğrenciler hakkında disiplin cezaları uygulanması da bu kapsamda yer alır. Yükseköğretim kurumu öğrencilerine ilişkin disiplin cezalarının çoğu, temel bir insan hakkı olan eğitim hakkının sınırlandırılması, hatta ortadan kaldırılması anlamına gelmektedir. Temel hak ve özgürlükler bakımından sınırlamalara yol açmaları, disiplin suç ve cezalarına ilişkin kuralların açı ve belirgin bir şekilde ortaya konulması gereğini doğurmaktadır. Bu itibarla ceza ve ceza muhakemesi hukukunda geçerli olan suçta ve cezada kanunilik ilkesi, savunma hakkına saygı ilkesi gibi ilkeler disiplin hukukunda da geçerli olmalıdır. Gerçekten de Anayasa’nın, temel hak ve hürriyetlerin, özlerine dokunulmaksızın yalnızca Anayasanın ilgili maddelerinde belirtilen sebeplere bağlı olarak ve ancak kanunla 
sınırlanabileceğini öngören 13. maddesi ile disiplin ve ceza işlerinin kanunla düzenleneceğini öngören 130/9. maddesi karşısında farklı düşünmek mümkün görünmemektedir. Ne var ki 2547 sayılı Kanunun yükseköğretim kurumu öğrencilerinin disiplin yönünden soruşturulmalarına ilişkin hususlarla, haklarında verilecek disiplin cezalarını düzenleyen 54. maddesi hükmünün genel çerçeveyi dahi çizmiş sayılmayacağı belirtilmelidir. 2547 sayılı Kanun m. 54 ile "Yönetmelikler" başlıklı m. 65-a’nın (9) numaralı düzenlemesine dayanılarak çıkarılan 'Yükseköğretim Kurumları Öğrenci Disiplin Yönetmeliği’nin pek çok düzenlemesi ise belirsiz ve tartışmalıdır. Bu itibarla konunun kanun ile ve "bireylerin hangi somut fiil ve olguya hangi hukuksal yaptırımın veya sonucun bağlandığını belirli bir açıklık ve kesinlikte öngörebilmelerine imkân verecek düzeyde kaleme alınmalarının” gerektiği vurgulanmalıdır. Daha açık bir ifade ile hangi fiillerin hangi disiplin cezalarını gerektireceği, disiplin işlemleri ve disiplin amirlerinin yetkileri gibi konular, kanunla ve açıklık ve kesinlik ilkelerini sağlayacak biçimde düzenlenmelidir.

\section{KAYNAKÇA}

ARPACIOĞLU, Işıl Tüzün/ MORGÜL Şükran: "Yükseköğretim Kurumları Öğrenci Disiplin Hukukuna 18.08.2012 Tarih ve 28388 Sayılı Resmi Gazete’de Yayımlanarak Yürürlüğe Giren Yükseköğretim Kurumları Öğrenci Disiplin Yönetmeliği ile Getirilen Yenilikler Üzerine Bir Değerlendirme”, Electronic Journal of Vocational Colleges (2013), Aralık UMYOS Özel Sayı, 79-86.

CENTEL, Nur/ ZAFER, Hamide/ ÇAKMUT, Özlem:Türk Ceza Hukukuna Giriş, Beta Yayıncılık, Ankara 2020. GÖZÜBÜYÜK, Şeref: Yönetim Hukuku, "S” Yayınları, Ankara, 1991.

GÖZÜBÜYÜK, Şeref/TAN, Turgut: İdare Hukuku, Ankara 2006.

GÜNAL, Yılmaz, “Disiplin Cezaları”, Ankara Üniversitesi Siyasal Bilgiler Fakültesi Dergisi (1958), Cilt 13, Sayı 2, ss. $190-211$.

GÜNDAY, Metin: İdare Hukuku, İmaj Yayınevi, Ankara, 2013.

GÜRER, Onur: Danıştay Kararları Işığında Öğrencilere Verilen Disiplin Cezalarının Yargısal Denetim, İstanbul Üniversitesi Sosyal Bilimler Enstitüsü Kamu Hukuku Anabilim Dalı, Yayınlanmamış Yüksek Lisans Tezi, İstanbul 2010.

KARABULUT, Mustafa: İdari Yaptırımların Hukuki Rejimi, Turhan Kitabevi, Ankara, 2008.

OĞURLU, Yücel: “Ceza Mahkemesi Kararının Disiplin Cezalarına Etkisi ve Sorunu "Ne Bis İn İdem” Kuralı", Ankara Üniversitesi Hukuk Fakültesi Dergisi (2003), Cilt 52, Sayı 2, ss. 101-124.

ÖZAY, İl Han: İdari Yaptırımlar, İstanbul: İstanbul Üniversitesi Yayınları, İstanbul, 1985.

TOROSLU, Haluk: Ceza Müeyyidesi, Ankara 2010.

TOROSLU, Nevzat: Ceza Hukuku Özel Kısım, Ankara: Savaş Yayınevi, Ankara, 2019.

TORTOP, Nuri: “Disiplin, Disiplin Cezaları ve Disiplin Suçları”, Amme İdaresi Dergisi (1983), Cilt 16, sayı 3, ss. 89-100.

TULKENS, Françoise: “The Paradoxical Relationship between Criminal Law and Human Rights”, Journal of International Criminal Justice (2011), Cilt 9, ss. 577-595, özl. s. 578 vd.

ULUSOY, Ali: İdari Yaptırımlar, On İki Levha Yayıncılık, İstanbul, 2013.

YILMAZ, Ejder: Hukuk Sözlüğü, Yetkin Yayınları, Ankara, 2005.

ZANOBINI, Guido: İdari Müeyyideler (Çev. H. Yılmaz Günal), Ankara Üniversitesi Siyasal Bilgiler Fakültesi Yayınları, Ankara, 1964. 